\title{
Karakteristik Edible Film Berbasis Pati Bentul (Colacasia Esculenta (L) Schoott) dengan Penambahan Gliserol dan Filtrat Kunyit Putih (Curcuma zedoaria Rosc)
}

\author{
Catherina Iskandar Putri ${ }^{1}$, Warkoyo ${ }^{1}$, Devi Dwi Siskawardani ${ }^{*}$ \\ Program Studi Teknologi Pangan, Fakultas Pertanian-Peternakan, Universitas Muhammadiyah \\ Malang, Malang, Indonesia \\ *Corresponding author email: devi@umm.ac.id
}

\begin{abstract}
Taro tubers contain $80 \%$ starch which has the potential as a raw material for making edible film. The addition of glycerol is used to increase the elasticity of the edible film. While the addition of white turmeric filtrate serves to increase the value ot the edible film function by containing antioxidant compounds. The purpose of this study was to determine the effect and interaction between the addition of glycerol concentration and white turmeric filtrate on the physicochemical characteristics of edible films. The research design used was a randomized complete block design (RCBD) factorial with two factors. The first factor was concentration of glycerol dan second factor was the concentration of white turmeric filtrate and consists of three replcations. Observation parameters include thickness, tensile strength, elongation, water vapor transmission rate, transparency, and antioxidant activity. The result showed that there was interaction between the different concentrations of glycerol and the concentration of white turmeric filtrate on the parameters of edible transparency. The addition of different concentrations of glycerol significantly affected the thickness, elongation, and transparency of the resulting edible film. Giving turmeric filtrate significantly affects the transparency and antioxidant value of the edible film. The best treatment on the results was in the A2B1 treatment (1\% glycerol and $0.8 \%$ white turmeric filtrate) which obtained a thickness value of $0.11 \mathrm{~mm}$ :

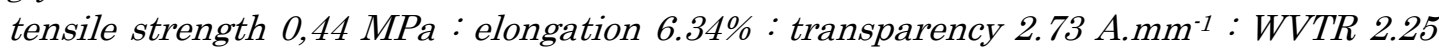
$\mathrm{g} / \mathrm{m}^{2} /$ day : and antioxidants $13.54 \%$.
\end{abstract}

Keywords: Antioxidants, Edible film, Plasticizer

Abstrak. Umbi bentul mengandung pati sebesar $80 \%$ yang berpotensi sebagai bahan baku
pembuatan edible film. Penambahan gliserol digunakan sebagai meningkatkan
elastisitas edible film. Penambahan filtrat kunyit putih berfungsi untuk meningkatkan
nilai fungsi edible film dengan mengandung senyawa antioksidan. Tujuan dari penelitian
ini untuk mengetahui pengaruh dan interaksi antara penambahan konsentrasi gliserol
dan filtrat kunyit putih terhadap karakteristik fisikokimia edible film. Rancangan
penelitian yang digunakan adalah Rancangan Acak Kelompok (RAK) Faktorial dengan
dua faktor yaitu faktor I konsentrasi gliserol dan faktor II adalah konsentrasi filtrat
kunyit putih dan terdiri dari tiga ulangan. Parameter pengamatan meliputi ketebalan,
kuat tarik, elongasi, laju transmisi uap air, transparansi dan aktivitas antioksidan. Hasil
penelitian menunjukkan bahwa terdapat interaksi antara perbedaan konsentrasi gliserol
dan konsentrasi filtrat kunyit putih terhadap parameter transparasi edible. Penambahan
perbedaan konsentrasi gliserol berpengaruh nyata terhadap ketebalan, elongasi, dan 
nilai transparasi edible film yang dihasilkan. Pemberian filtrat kunyit berpengaruh nyata terhadap transparasi dan nilai antioksidan edible film yang dihasilkan. Perlakuan terbaik pada penelitian ini terdapat pada perlakuan A2B1 (Gliserol 1\% dan filtrat kunyit putih $0.8 \%$ ) yang mendapatkan hasil nilai ketebalan $0.11 \mathrm{~mm}:$ kuat tarik 0.44 $\mathrm{MPa}$ : elongasi $6.34 \%$ : transparansi 2.73 A.mm ${ }^{-1}$ : WTVR $2.25 \mathrm{~g} / \mathrm{m}^{2} / 24 \mathrm{jam}$ : dan antioksidan $13.54 \%$.

Kata kunci: Antioksidan, Edible film, Plasticizer

\section{PENDAHULUAN}

Produk makanan sangat penting untuk diberi kemasan agar produk terlindungi dari cemaran yang dapat menyebabkan kerusakan. Edible film merupakan salah satu teknologi alternatif kemasan yang memiliki sifat biodegradable yang ramah lingkungan. Edible film dikelompokkan menjadi dua jenis, yaitu yang berfungsi sebagai pelapis (coating) dan lembaran (film). Edible coating telah banyak digunakan untuk melapisi produk daging beku, makanan semi basah, buah-buahan, sayuran, dan kapsul atau obat-obatan. Edible film merupakan lapisan tipis yang digunakan untuk melapisi makanan yang berfungsi sebagai penahan terhadap transfer massa seperti kadar air, oksigen, lemak, dan cahaya atau berfungsi sebagai pembawa bahan tambahan pangan (Megawati, 2015). Salah satu bahan alami yang digunakan dalam pembuatan edible film yaitu hidrokoloid, lipid atau komposit.

Pati merupakan jenis hidrokoloid yang dapat digunakan sebagai bahan baku pembuatan edible film. Pati mengandung dua penyusun penting yang dapat mempengaruhi kestabilan dan kekuatan edible film, yakni amilosa dan amilopektin (Cerqueira dkk., 2011). Bentul merupakan sumber pati yang berasal dari umbi-umbian yang mudah ditemui dan berpotensi sebagai bahan baku pembuatan edible film. Bentul memiliki kandungan pati yang cukup tinggi yaitu sebesar 80\% (Rahmawati, dkk., 2012). Berdasarkan dari sumber tanamannya, pati bentul mengandung 20-25\% amilosa dan 75-80\% amilopektin (Karmakar dkk., 2014). Edible film berbasis pati memiliki sifat hidrofilik, mudah rapuh, permeabilitas uap air tinggi, dan kurang fleksibel. Oleh karenanya perlu ditambahkan plasticizer agar elastis (Warkoyo dkk., 2014).

Plasticizer yang sering digunakan dalam pembuatan edible film yaitu gliserol. Gliserol $\left(\mathrm{C}_{3} \mathrm{H}_{8} \mathrm{O}_{3}\right)$ merupakan senyawa alkohol trihidrat. Gliserol memiliki sifat mudah mengabsorpsi air, kandungan energi, dan indeks kelarutan yang tinggi di dalam air (Wulandari, 2021). Gliserol dapat berperan sebagai plasticizer dalam edible film karena memiliki volatilitas rendah, memberi sifat fleksibilitas dan elastisitas rantai polimer pada edible film yang dihasilkan (Bourtoom, 2007).

Bahan aktif perlu ditambahkan pada larutan edible untuk menambah fungsi pada edible film. Kunyit putih (Curcuma zedoria Rosc mengandung 
senyawa bersifat antioksidan. Pada kunyit putih terdapat senyawa metabolit sekunder golongan flavonoid, polifenol, dan triterpenoid (Rita, 2010). Aktivitas antioksidan berperan dalam penangkapan radikal bebas dan spesies oksigen reaktif. Senyawa antioksidan yang ditambahkan pada bahan makanan bertujuan untuk mempertahankan waktu penyimpanan bahan pangan agar tidak mudah mengalami oksidasi lemak dan minyak, menghambat proses kerusakan makanan, dan meningkatkan stabilitas lemak yang terkandung dalam makanan (Saputra dan Purwanti, 2016).

Berdasarkan penelitian sebelumnya yaitu pembuatan edible film pati tapioka dengan penambahan gliserol dan kunyit putih oleh (Muin dkk, 2017) menghasilkan edible film yang memiliki sifat antimikroba. Namun selain memiliki sifat antimikroba, edible film dapat bersifat fungsional bila dikombinasikan dengan bahan aktif yang mengandung senyawa antioksidan. Oleh karena itu, perlu dilakukan penilitian untuk mengetahui pengaruh edible film dari pati bentul yang ditambahkan filtrat kunyit putih dan gliserol dengan perbedaan konsentrasi.

\section{METODE PENELITIAN}

Alat

Alat-alat yang digunakan dalam proses pembuatan edible film adalah pisau, blender, saringan pengayak, baskom, gelas beker, timbangan analitik, loyang 20x20 cm, plat kaca, batang pengaduk, pipet tetes, spatula, kertas saring, thermometer, stopwatch, papan potong, kertas saring, gunting, cabinet dryer, plastik, hotplate. Alat- alat yang digunakan untuk analisa edible film yaitu spektrofometer UV-Vis double beam, mikrometer manual $0,01 \mathrm{~mm}$, universal testing machine merek Zwick/z 0,5.

\section{Bahan}

Bahan yang digunakan dalam pembuatan edible film yaitu umbi bentul dengan umur panen 8 bulan dan kunyit putih dengan umur panen 8 bulan yang diperoleh dari Pasar Tradisional Gadang Kota Malang. Kemudian bahan pendukung meliputi aquades, gliserol pro analis (PA), kemudian bahan yang digunakan untuk analisa yaitu etanol 96\%, silica gel yang diperoleh dari Toko Nurra Gemilang, DPPH(2,2-difenil-1-pikrilhidrazil), dan larutan $\mathrm{NaCl} 40 \%$.

\section{Desain Penelitian}

Penelitian ini menggunakan Rancangan Acak Kelompok (RAK) Faktorial yang terdiri dari dua faktor yang diulang sebanyak tiga kali, sehingga kombinasi yang dilakukan berjumlah Sembilan. Faktor pertama yaitu konsentrasi penggunaan gliserol, dan faktor kedua yaitu konsentrasi penambahan filtrat kunyit putih. 


\section{Pembuatan Pati Bentul}

Pembuatan pati bentul dilakukan dengan modifikasi penelitian (Misni dan Syahbanu, 2017). Sebanyak 100 gram umbi bentul dicuci dengan air kemudian ditiriskan. Umbi bentul dipisahkan dari kulit, lalu dipotong berbentuk kubus dan direndam dengan larutan $\mathrm{NaCl}$ 10\% selama satu jam untuk menghilangkan asam oksalat pada bentul. Kemudian umbi bentul ditambahkan air sebanyak $100 \mathrm{~mL}$ dan dihaluskan. Setelah bentul halus disaring menggunakan kain. Filtrat yang diperoleh didiamkan selama 24 jam hingga terbentuk endapan. Hasil endapan pati yang diperoleh dikeringkan menggunakan cabinet dryer dengan suhu $60{ }^{\circ} \mathrm{C}$ selama 20 jam. Pati yang telah kering ditimbang hingga massa pati konstan.

\section{Pembuatan Filtrat Kunyit Putih}

Langkah Awal dalam pembuatan filtrat kunyit putih, yaitu kunyit dicuci menggunakan air mengalir hingga bersih. Setelah dicuci, kunyit di kupas dan di potong dengan ketebalan kurang lebih $2 \times 2 \mathrm{~cm}$ serta dihaluskan menggunakan blender. Kunyit yang telah halus di peras dan sari kunyit di saring dengan kertas saring sehingga di dapatkan filtrat kunyit (Harini dkk., 2020).

\section{Pembuatan Edible Film}

Pembuatan edible film dibuat dari modifikasi penelitian (Pangesti dkk., 2014). Langkah pertama yaitu pati bentul ditimbang menggunakan konsentrasi pati bentul sebanyak 4 gram. Pati bentul dilarutkan ke dalam $100 \mathrm{~mL}$ aquades dan di tambahkan gliserol sesuai dengan perlakuan ( $1 \mathrm{~mL}: 1,25 \mathrm{~mL}: 1,5 \mathrm{~mL}$ ). Kemudian larutan dipanaskan di atas hot plate stirrer sampai mencapai suhu 85 ${ }^{\circ} \mathrm{C}$ dan dilakukan penurunan suhu hingga mencapai $40{ }^{\circ} \mathrm{C}$. Ditambahkan filtrat kunyit putih sesuai dengan perlakuan $(0,8 \mathrm{~mL}: 1,2 \mathrm{~mL}: 1,6 \mathrm{~mL})$ ke dalam larutan dengan kondisi yang sama. Larutan edible film dituang ke dalam cetakan dan dilakukan pengeringan dengan cabinet dryer pada suhu $55{ }^{\circ} \mathrm{C}$ selama 24 jam. Pengeringan dihentikan saat edible film mudah lepas dari cetakan.

\section{Parameter Penelitian}

Edible film yang dihasilkan dilakukan analisa dengan parameter ketebalan (Warkoyo dkk, 2014), kuat tarik, elongasi, laju transmisi uap air (ASTM D882-12, 2012), transparasi (Setiani dkk., 2013), dan aktivitas antioksidan dengan metode DPPH (Pratiwi dkk., 2013). Perlakuan terbaik didapat setelah dilakukan analisa perhitungan metode de garmo.

\section{Analisa Data}

Pengolahan data dilakukan menggunakan analisis variasi (ANOVA) untuk mendapatkan kesimpulan dari setiap perlakuan. Kemudian dilanjutkan uji banding Duncant's Multiple Range Test (DMRT) dengan taraf nyata 5\% ( $\alpha=0,05)$ untuk mendapatkan kesimpulan mengenai pengaruh perlakuan terhadap karakteristik fisikokimia edible film berbasis pati bentul. 


\section{HASIL DAN PEMBAHASAN}

\section{Analisis Bahan Baku}

Bahan baku dianalisa terlebih dahulu sebelum pembuatan larutan edible film. Analisa pada pati bentul meliputi kadar air, kadar pati, amilosa, dan amilopektin. Hasil analisa ditunjukkan pada Tabel 1.

Tabel 1. Analisa Bahan Baku

\begin{tabular}{lcc}
\hline \multicolumn{1}{c}{ Komponen Kimia } & Hasil Analisa & Literatur $\left(^{*}\right)$ \\
\hline Kadar Air Pati Bentul (\%) & 9,65 & 13,18 \\
Kadar Pati Bentul (\% bk) & 71,69 & 80 \\
Amilosa Bentul (\% bk) & 33,02 & 25,55 \\
Amilopektin Bentul (\% bk) & 66,98 & 74,45 \\
\hline
\end{tabular}

Sumber : (*) Rahmawati, (2012)

Berdasarkan Tabel 1 didapatkan hasil kadar air pati umbi bentul yaitu 9,65\%, kadar pati 71,69\%, amilosa 33,02\%, dan amilopektin 66,98\%. Kadar air selalu dikaitkan dengan mutu bahan, sehingga memiliki peran penting terhadap penyimpanan agar tidak mudah mengalami kerusakan. Semakin tinggi nilai kadar air dari suatu bahan maka semakin cepat terjadi kerusakan bahan pangan tersebut akibat adanya mikroorganisme. Menurut SNI (BSN 2011), kadar air dari pati tidak melebihi 14\%, sehingga kadar air telah sesuai dengan standar mutu. Prosentase kandungan total pati yang didapat lebih rendah dari literatur. Beberapa faktor dapat menyebabkan adanya perbedaan total kandungan kimia yaitu perbedaan varietas, lingkungan tumbuh, umur panen dan penanganan pasca panen. Kadar pati umbi yang dipanen pada musim kemarau relatif lebih tinggi karena kadar air umbi yang diperoleh lebih sedikit (Yulianti, 2012). Pati mengandung amilosa dan amilopektin yang dapat mempengaruhi sifat derajat gelatinisasi dan kelarutan (Nisah, 2018).

Bahan baku selanjutnya yaitu kunyit putih yang berfungsi sebagai bahan aktif. Penambahan bahan aktif akan menambah nilai fungsi pada edible film karena terdapat senyawa antioksidan. Berdasarkan hasil analisa yang telah dilakukan, kadar antioksidan yang terkandung pada filtrat kunyit putih sebesar 47,23\%. Menurut Pujimulyani dkk (2010), kunyit putih mengandung senyawasenyawa bioaktif seperti fenol, flavonoid, tannin yang bersifat antioksidan dan juga antimikroba. Masing-masing senyawa bioaktif memberikan peran dalam menghambat aktivitas mikroba. Senyawa fenol yang terkandung di dalam kunyit putih yaitu kurkumin.

\section{Analisa Fisikokimia Edible Film Ketebalan Edible Film}


Berdasarkan hasil analisis ragam menunjukkan bahwa tidak terdapat interaksi antara konsentrasi gliserol dan filtrat kunyit putih. Namun, secara terpisah pada penambahan konsentrasi gliserol memberikan pengaruh nyata terhadap ketebalan edible film. Nilai ketebalan edible film dengan penambahan variasi konsentrasi gliserol dapat dilihat pada Tabel 2.

Tabel 2. Ketebalan Edible Film Perlakuan Konsentrasi Gliserol

\begin{tabular}{lc}
\hline \multicolumn{1}{c}{ Konsentrasi Gliserol } & Ketebalan $(\mathrm{mm})$ \\
\hline A1 (Gliserol dengan konsentrasi 0,75\%) & $0,11^{\mathrm{a}}$ \\
A2 (Gliserol dengan konsentrasi 1\%) & $0,12^{\mathrm{a}}$ \\
A3 (Gliserol dengan konsentrasi 1,25\%) & $0,14^{\mathrm{b}}$ \\
\hline
\end{tabular}

Keterangan : Nilai rata-rata yang diikuti huruf yang berbeda menunjukkan perbedaan nyata menurut uji Duncan (a 5\%).

Ketebalan merupakan parameter penting yang mempengaruhi penggunaan film pada suatu produk. Nilai ketebalan edible film pada perlakuan konsentrasi gliserol menunjukkan hasil yang berbeda nyata dan didapat nilai berkisar antara 0,11- 0,14 mm. Bertambahnya konsentrasi gliserol yang digunakan, menyebabkan ketebalan pada edible film semakin meningkat. Hal ini dikarenakan gliserol memiliki sifat yang mudah larut dalam air dan dapat meningkatkan viskositas larutan. Penelitian sebelumnya yang dilakukan Barus (2002) dalam Baskara (2012), yang menyatakan bahwa peningkatan edible film dipengaruhi oleh perbedaan konsentrasi bahan baku yang digunakan. Selain itu, peningkatan konsentrasi gliserol yang ditambahkan juga mempengaruhi tingkat viskositas, sehingga dapat meningkatkan nilai ketebalan dari edible film. Semakin meningkat konsentrasi bahan yang digunakan dapat meningkatkan ketebalan edible film berdasarkan formula yang digunakan (Baskara, 2012). Sedangkan pada proses pengeringan juga dapat mempengaruhi ketebalan dikarenakan jumlah total padatan telarut dalam film meningkat dan polimer penyusun matriks pada edible film juga semakin banyak (Roosdiana dkk, 2017).

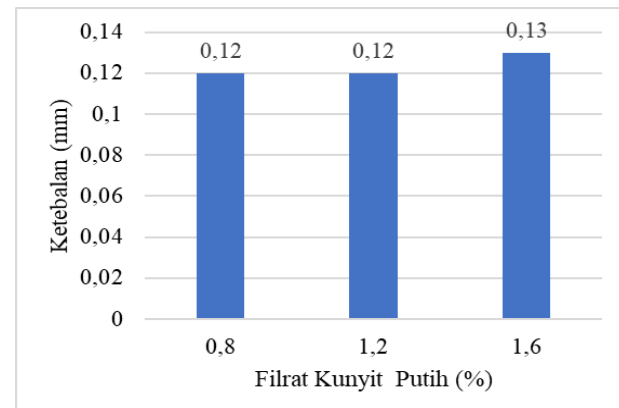

Gambar 1. Nilai Ketebalan Ketebalan Edible Film Perlakuan Konsentrasi Filtrat Kunyit Putih

Penambahan filtrat kunyit putih tidak berpengaruh secara nyata terhadap ketebalan edible film. Pada Gambar 1 Menyajikan nilai rerata ketebalan edible film yang berkisar 0,12-0,13mm. Hal ini terjadi karena filtrat kunyit putih tidak 
mengandung pati yang akan menambah total padatan terlarut. Hal tersebut tidak sesuai dengan pernyataan (Muin,2017) bahwa penambahan kunyit putih mempengaruhi ketebalan edible film dikarenakan kunyit putih dapat meningkatkan jumlah total padatan, sehingga tebal film akan lebih padat. Menurut (Amaliya, 2013), bahwa penambahan total padatan berasal dari pati kunyit putih yang tidak tersaring sempurna sehingga senyawa tersuspensi seperti pati dapat meningkatkan ketebalan edible film. Selain itu (Kolopita, 2018) menyatakan bahwa beberapa faktor yang dapat mempengaruhi ketebalan edible film meliputi luas cetakan, komponen penyusun, dan volume suspensi.

Nilai ketebalan edible film yang dihasilkan telah sesuai dengan syarat yang ditetapkan oleh Japanese Industrial Standards, (1975) yaitu memiliki nilai $<0,250 \mathrm{~mm}$. Ketebalan merupakan karakteristik yang penting dalam menentukan kelayakan edible film sebagai kemasan produk pangan karena ketebalan sangat mempengaruhi sifat fisik dan mekanik lainnya, seperti kuat tarik, pemanjangan, daya larut dan permeabilitas uap air (Rusli dan Tahir,2017).

\section{Water Vapor Transmission Rate (WVTR) Edible Film}

Berdasarkan analisis ragam menunjukkan tidak ada interaksi antara perlakuan konsentrasi gliserol dan penambahan konsentrasi filtrat kunyit putih. Adapun rerata nilai laju transmisi uap air dengan perbedaan konsentrasi gliserol dapat dilihat pada Gambar 2 dan konsentrasi filtrat kunyit putih pada Gambar 3.

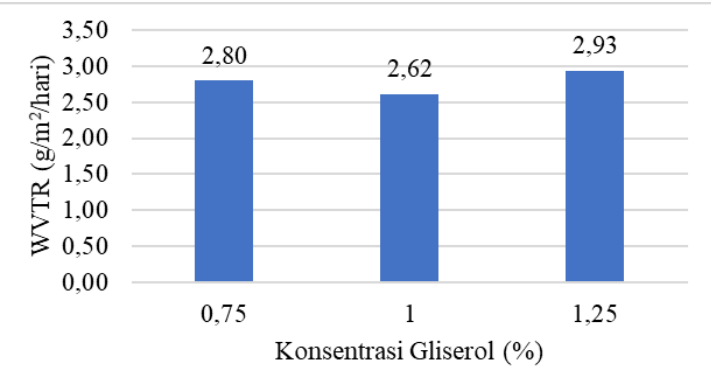

Gambar 2. WVTR Edible Film Perlakuan Konsentrasi Gliserol

Laju transmisi uap air atau water vapor transmission rate (WVTR) merupakan salah satu sifat penting pada edible film. Nilai WVTR dapat digunakan untuk mengetahui nilai permeabilitas suatu bahan terhadap uap air. Berdasarkan Gambar 2, perlakuan penambahan gliserol dengan konsentrasi yang berbeda tidak berpengaruh secara nyata. Nilai rerata laju transmisi uap air berkisar antara $2,62-2,93\left(\mathrm{~g} / \mathrm{m}^{2} /\right.$ hari). Nilai laju transmisi uap air pada edible film meningkat seiring bertambahnya konsentrasi gliserol. Hal ini dikarenakan konsentrasi gliserol yang meningkat dapat menyebabkan interaksi antar molekul menjadi lemah, sehingga kerapatan molekul menjadi berkurang dan terbentuk ruang bebas pada matriks film dan memudahkan difusi uap air (Polnaya dkk, 2016). Sesuai dengan pernyataan Amaliya dan Putri (2014), bahwa plasticizer 
bersifat hidrofilik yang mampu menurunkan tegangan antar molekul pada matriks dan menyebabkan ruang antar molekul semakin besar sehingga uap air dapat menembus edible film. Selain itu, sifat hidrofilik gliserol dapat menurunkan sifat hidrofobik dan meningkatkan sifat higroskopis pada film sehingga mudah menyerap uap air dan dapat meningkatkan nilai laju transmisi uap air pada edible film (Akili, 2012).

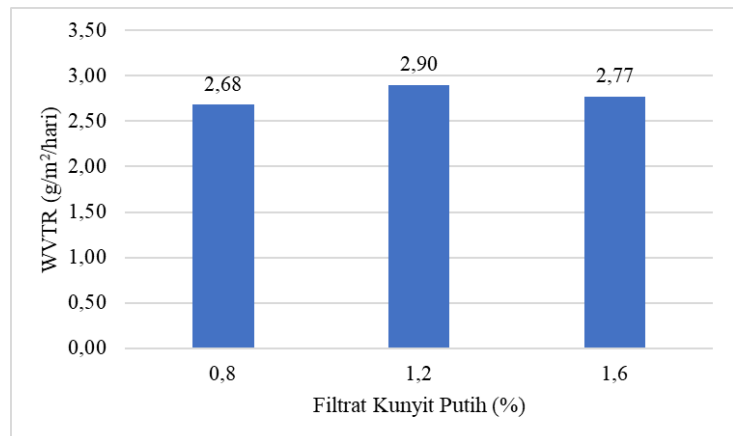

Gambar 3. WVTR Edible Film Perlakuan Konsentrasi Filtrat Kunyit Putih

Berdasarkan Gambar 3 perlakuan konsentrasi filtrat kunyit putih yang berbeda tidak berpengaruh nyata terhadap nilai laju transmisi uap air pada edible film. Nilai laju transmisi uap air film yang dihasilkan pada penelitian ini berkisar 2,68-2,90 (g/m²/hari). Penambahan konsentrasi filtrat kunyit putih meningkatkan laju transmisi uap air. Hal ini dikarenakan pada penambahan bahan aktif dapat mengurangi kerapatan molekul, sehingga menciptakan ruang kosong pada matriks film yang mempermudah difusi uap air. Tipe bahan aktif yang ditambahkan akan menghasilkan edible film dengan permeabilitas uap air yang berbeda-beda (Warsiki dkk., 2009). Hasil penelitian terdahulu yang dilakukan oleh hakim (2018) menyatakan bahwa semakin tinggi konsentrasi ekstrak jahe merah dapat meningkatkan nilai laju transmisi uap air. Berdasarkan Japan Industrial Standard (1975) standar maksimal nilai laju transmisi uap air tidak lebih dari 7 (g/m²/hari), maka nilai rerata yang dihasilkan dari penelitian ini dapat dikatakan telah sesuai dengan standar yang ditetapkan.

\section{Kuat Tarik Edible Film}

Berdasarkan analisis ragam diketahui bahwa tidak terdapat interaksi antara konsentrasi gliserol konsentrasi filtrat kunyit putih terhadap kuat tarik edible film yang dihasilkan. Nilai rerata kuat Tarik edible film dapat dilihat pada Gambar 4 dan Gambar 5. 


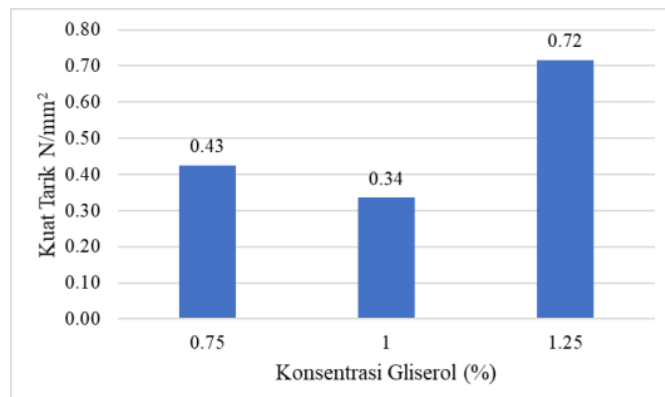

Gambar 4. Kuat Tarik Edible Film Perlakuan Konsentrasi Gliserol

Berdasarkan analisis ragam diketahui bahwa tidak terdapat interaksi antara konsentrasi gliserol konsentrasi filtrat kunyit putih terhadap kuat tarik edible film yang dihasilkan. Nilai rerata kuat Tarik edible film dapat dilihat pada Gambar 4 dan Gambar 5.

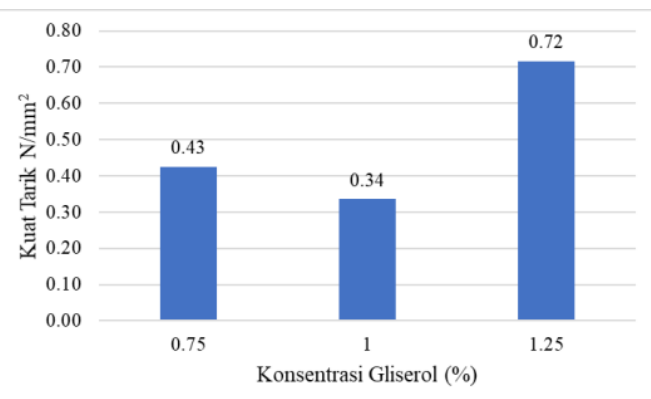

Gambar 5. Kuat Tarik Edible Film Perlakuan Konsentrasi Gliserol

Berdasarkan Gambar 4. diatas menunjukkan bahwa peningkatan konsentrasi gliserol tidak berpengaruh nyata terhadap nilai kuat tarik edible film yang dihasilkan. Nilai rerata kuat tarik berkisar 0,34-0,72 $\mathrm{N} / \mathrm{mm}^{2}$. Nilai kuat tarik tertinggi terdapat pada perlakuan A3 (konsentrasi gliserol 1,25\%) sebesar $0,72 \mathrm{~N} / \mathrm{mm}^{2}$ dan nilai terendah terdapat pada perlakuan A1 (konsentrasi gliserol 0,75\%) sebesar 0,34 N/mm². Hasil data kuat Tarik perlakuan A2 dan A3 telah sesuai dengan Japan Industrial Standard (1975) yaitu bernilai minimal sebesar $0,392 \mathrm{~N} / \mathrm{mm}^{2}$. Nilai kuat tarik cenderung meningkat akibat penambahan konsentrasi gliserol. Hal tersebut tidak sesuai dengan pernyataan (Unsa dan paramastri, 2018), bahwa bertambahnya konsentrasi gliserol dapat menyebabkan nilai kuat tarik semakin rendah. Hal tersebut dikarenakan plasticizer dapat mengurangi energi yang dibutuhkan molekul untuk melakukan pergerakan sehingga kekakuan menurun. Penambahan plasticizer juga dapat mengurangi ikatan hidrogen internal molekul dan menyebabkan melemahnya gaya tarik intermolekul rantai polimer yang berdekatan sehingga mengurangi daya regang putus (Putra, 2017). Hasil tersebut juga didukung pada penelitian (Riza dkk., 2013), bahwa Peningkatan konsentrasi plasticizer dapat menurunkan ikatan hidrogen dalam edible film sehingga meningkatkan fleksibilitas maka kuat tarik 
juga semakin kecil, karena film yang dihasilkan menjadi lebih lentur, lembut, dan fleksibel sehingga kuat tarik cenderung menurun.

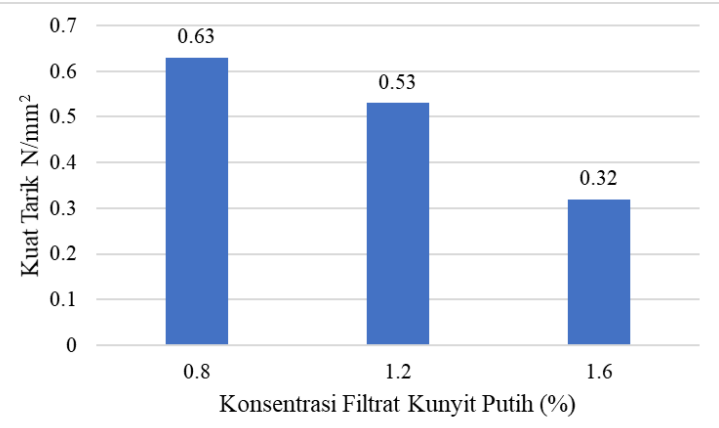

Gambar 6. Kuat Tarik Edible Film Perlakuan Konsentrasi Filtrat Kunyit Putih

Berdasarkan Gambar 5 menunjukkan bahwa peningkatan konsentrasi filtrat kunyit putih tidak berpengaruh nyata terhadap kuat tarik edible film yang dihasilkan. Nilai rerata kuat tarik berkisar $0,32-0,63 \mathrm{~N} / \mathrm{mm}^{2}$. Nilai kuat tarik tertinggi terdapat pada perlakuan B1 (konsentrasi filtrat 0,8\%) sebesar 0,63 $\mathrm{N} / \mathrm{mm}^{2}$ dan nilai terendah terdapat pada perlakuan B3 (konsentrasi filtrat 1,6\%) sebesar $0,32 \mathrm{~N} / \mathrm{mm}^{2}$. Nilai kuat Tarik cenderung menurun seiring bertambahnya konsentrasi filtrat kunyit putih. Hal ini sesuai dengan pendapat Warkoyo (2014), bahwa kekuatan tarik dari edible film melemah seiring dengan meningkatnya penambahan konsentrasi bahan aktif. Hal ini dapat dikarenalan interaksi antar molekul dapat melemah seiring dengan bertambahnya jumlah bahan aktif yang ditambahkan. Menurut Julianur (2015), nilai kuat tarik merupakan nilai gaya maksimum yang dibutuhkan untuk menarik sebuah edible film. Semakin besar gaya yang dibutuhkan maka semakin besar nilai kuat tarik dan semakin baik dalam melindungi produk dari gangguan mekanis.

\section{Elongasi Edible Film}

Berdasarkan analisis ragam menunjukkan bahwa tidak ada interaksi antara perlakuan perbedaan konsentrasi gliserol dan filtrat kunyit putih. Namun secara terpisah perlakuan konsentrasi gliserol berpengaruh nyata terhadap prosentase pemanjangan (elongasi), sedangkan konsentrasi filtrat kunyit putih tidak berbeda nyata terhadap prosentase pemanjangan edible film. Rerata prosentase pemanjangan dapat dilihat pada Tabel 3 dan Gambar 6 .

Tabel 3. Elongasi Edible Film Perlakuan Perbedaan Konsentrasi Gliserol

\begin{tabular}{lc}
\hline \multicolumn{1}{c}{ Konsentrasi Gliserol } & Elongasi (\%) \\
\hline A1 (Gliserol dengan konsentrasi 0,75\%) & $5,16^{\mathrm{a}}$ \\
A2 (Gliserol dengan konsentrasi 1\%) & $7,67^{\mathrm{ab}}$ \\
A3 (Gliserol dengan konsentrasi 1,25\%) & $8,32^{\mathrm{b}}$ \\
\hline
\end{tabular}

Keterangan : Nilai rata-rata yang diikuti huruf yang berbeda menunjukkan perbedaan nyata menurut uji Duncan (a 5\%). 
Berdasarkan Tabel 3 Didapat hasil rerata nilai pemanjangan edible film terdapat pada perlakuan A3 (konsentrasi gliserol 1,25\%) dengan nilai elastisitas 8,32\% dan terendah pada perlakuan A1 (konsentrasi gliserol 0,75\%) sebesar $5,16 \%$. Konsentrasi gliserol yang meningkat menyebabkan nilai elongitas semakin besar. Hal ini sesuai dengan pernyataan (Coniwati dkk, 2015), bahwa semakin banyak gliserol yang ditambahkan maka edible film yang dihasilkan semakin elastis. Tingkat elastisitas yang bernilai besar menunjukan semakin mudah edible film dapat digunakan karena memiliki nilai fleksibilitas yang tinggi. Menurut Irawan (2010), peningkatan jumlah gliserol dapat menurunkan kekuatan gaya antar molekul sehingga mobilitas antar rantai molekul meningkat dan persentase elongasi edible film pun semakin meningkat. Namun jika penggunaan gliserol yang berlebihan dapat menghasilkan banyak gelembung dan peregangan ruang terlalu besar sehingga edible film mudah sobek (Muin, 2017).

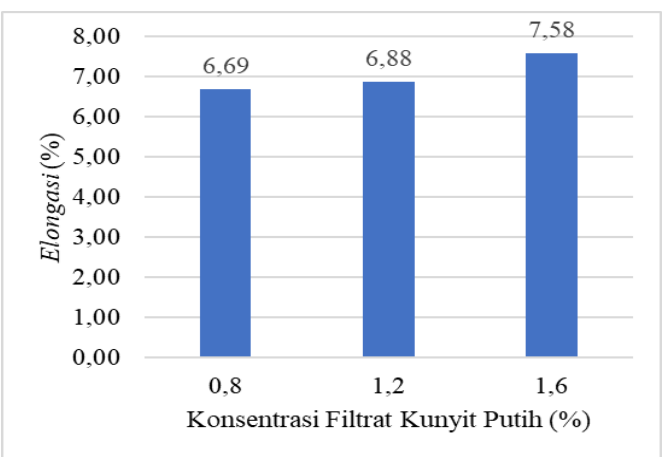

Gambar 7. Elongasi Edible Film Perlakuan Perbedaan Konsentrasi Filtrat Kunyit Putih

Berdasarkan Gambar 6. dapat diketahui bahwa penambahan konsentrasi filtrat kunyit putih tidak berpengaruh nyata terhadap elongasi (persen pemanjangan) pada edible film yang dihasilkan. Nilai rerata persen pemanjangan berkisar antara 6,69\% - 7,58\%. Persentasi pemanjangan meningkat seiring dengan konsentrasi filtrat kunyit putih yang bertambah. Hal ini tidak sesuai dengan pernyataan (Amaliya dan Putri, 2013), bahwa penambahan filtrat kunyit putih dapat menurunkan nilai elongasi edible film. Hal ini diduga filtrat kunyit masih mengandung total padatan terlarut yang tidak tersaring sempurna. Total padatan terlarut mampu memperkokoh matriks film sehingga mampu mengurangi nilai elongasinya. Berdasarkan Japan Industrial Standard (1975) nilai elongasi yang ditetapkan yaitu <10\% kurang baik, 10\%-50\% baik dan $>50 \%$ sangat baik. Nilai elongasi yang dihasilkan dari penelitian ini berkisar 5,16\% 8,32\% sehingga dapat dikatakan bahwa nilai elongasi yang dihasilkan tergolong buruk. 


\section{Transparasi Edible Film}

Berdasarkan analisis ragam menunjukan bahwa terdapat interaksi antar perlakuan penambahan gliserol dan filtrat kunyit putih. Penambahan konsentrasi gliserol dan konsentrasi filtrat kunyit putih berpengaruh nyata terhadap transparansi edible film.

Tabel 4. Transparasi Edible Film Perlakuan Konsentrasi Gliserol

\begin{tabular}{lc}
\hline \multicolumn{1}{c}{ Konsentrasi Gliserol } & $\begin{array}{c}\text { Transparasi } \\
(\mathrm{A} / \mathrm{mm})^{-1}\end{array}$ \\
\hline A1 (Gliserol dengan konsentrasi 0,75\%) & $3,38^{\mathrm{b}}$ \\
A2 (Gliserol dengan konsentrasi 1\%) & $2,99^{\mathrm{ab}}$ \\
A3 (Gliserol dengan konsentrasi 1,25\%) & $2,78^{\mathrm{a}}$ \\
\hline
\end{tabular}

Keterangan : Nilai rata-rata yang diikuti huruf yang berbeda menunjukkan perbedaan nyata menurut uji Duncan (a 5\%).

Berdasarkan Tabel 4 dapat dilihat bahwa penambahan gliserol berpengaruh nyata terhadap nilai transparansi edible film. Nilai rerata transparansi edible film yang dihasilkan yaitu 2,78 - $3,38(\mathrm{~A} / \mathrm{mm})^{-1}$. Nilai Transparasi tertinggi terdapat pada perlakuan A1 (konsentrasi gliserol 0,75\%) sebesar 3,38 (A/mm $)^{-1}$ dan nilai terendah yaitu $2,78(\mathrm{~A} / \mathrm{mm})^{-1}$ terdapat pada A3 (konsentrasi gliserol 1,25\%). Semakin tinggi konsentrasi gliserol dapat menyebabkan nilai transparasi edible film yang dihasilkan menurun. Hal tersebut sesuai dengan pernyataan Huri (2014), bahwa nilai transparasi cenderung menurun seiring dengan peningkatan konsentrasi gliserol yang ditambahkan maka derajat transparasi (kejernihan) cenderung meningkat. Seperti yang dikemukakan Al-Hasan dan Norziah (2012) bahwa, derajat kejernihan film dengan plasticizer sorbitol semakin meningkat pada rasio pati : gelatin yang meningkat, sedangkan edible film tanpa plasticizer menghasilkan derajat transparansi yang lebih tinggi.

Tabel 5. Transparasi Edible Film Perlakuan Konsentrasi Filtrat Kunyit Putih

\begin{tabular}{cc} 
Konsentrasi Filtrat Kunyit Putih & $\begin{array}{c}\text { Transparasi } \\
(\mathrm{A} / \mathrm{mm})^{-1}\end{array}$ \\
\hline B1 (Filtrat kunyit putih dengan konsentrasi 0,8\%) & $2,78^{\mathrm{a}}$ \\
B2 (Filtrat kunyit putih dengan konsentrasi 1,2\%) & $2,94^{\mathrm{a}}$ \\
B3 (Filtrat kunyit putih dengan konsentrasi 1,6\%) & $3,43^{\mathrm{b}}$ \\
\hline
\end{tabular}

Keterangan : Nilai rata-rata yang diikuti huruf yang berbeda menunjukkan perbedaan nyata menurut uji Duncan (a 5\%).

Berdasarkan hasil analisa ragam menunjukkan bahwa penambahan filtrat kunyit berpengaruh nyata terhadap transparansi edible film yang dihasilkan. Nilai rerata yang dihasilkan dengan penambahan konsentrasi filtrat kunyit yaitu berkisar 2,78 - 3,43 (A/mm $)^{-1}$. Nilai transparasi tertinggi terdapat pada perlakuan A3 (konsentrasi filtrat kunyit putih 1,6\%) sebesar 3,43 (A/mm)-1 dan nilai terendah yaitu $2,78^{\mathrm{a}}(\mathrm{A} / \mathrm{mm})^{-1}$ terdapat pada perlakuan A1 (konsentrasi filtrat kunyit putih 0,8\%). Dapat dilihat pada Tabel 5 bahwa penambahan konsentrasi filtrat kunyit putih menghasilkan nilai transparansi edible film semakin tinggi. Hal ini dikarenakan semakin banyak filtrat kunyit yang ditambahkan dapat 
menyebabkan warna yang diserap oleh pembaca absorbansi akan semakin banyak, sehingga edible film yang dihasilkan akan semakin keruh dan tingkat kejernihan berkurang. Selain itu, transparansi cenderung meningkat seiring dengan bahan aktif yang ditambahkan meningkat, artinya bahwa semakin tinggi penambahan filtrat kunyit maka transparansi cenderung menurun (Saragih. dkk, 2016).

\section{Aktivitas Antioksidan Edible Film}

Berdasarkan analisis ragam dapat diketahui bahwa tidak ada interaksi antara perlakuan perbedaan konsentrasi gliserol dengan konsentrasi filtrat kunyit putih terhadap aktivitas antioksidan. Secara terpisah perlakuan konsentrasi gliserol tidak berpengaruh nyata terhadap aktivitas antioksidan, sedangkan peningkatan konsentrasi filtrat kunyit putih berpengaruh nyata terhadap aktivitas antioksidan. Nilai rerata aktivitas antioksidan perlakuan konsentrasi gliserol dapat dilihat pada Gambar 7 dan perlakuan konsentrasi filtrat kunyit putih pada Tabel 6 .

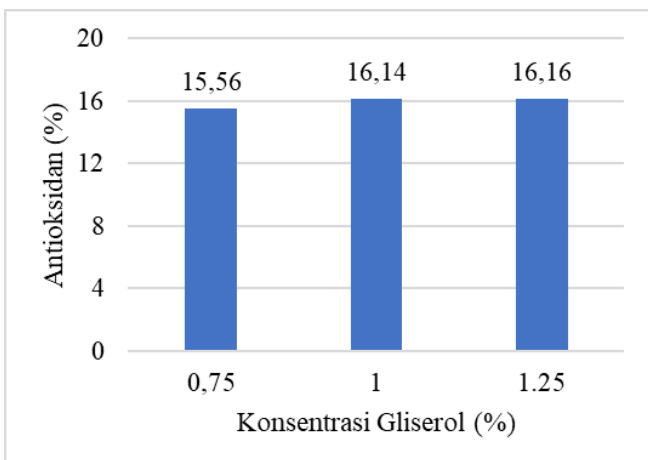

Gambar 8. Aktivitas Antioksidan Perlakuan Konsentrasi Gliserol

Berdasarkan Gambar 7 penambahan konsentrasi gliserol yang berbeda tidak berpengaruh nyata terhadap aktivitas antioksidan pada edible film yang dihasilkan. Nilai yang didapat berkisar 15,56\% - 16,16\%. Perlakuan konsentrasi gliserol menyebabkan kenaikan yang tidak signifikan terhadap nilai aktivitas antioksidan. Hal ini sesuai dengan penelitian Huri dan Nisa (2014), bahwa perlakuan gliserol menyebabkan nilai aktivitas antioksidan meningkat tetapi tidak signifikan pada edible film. Kenaikan aktivitas antioksidan disebabkan fenol mempunyai kontribusi terhadap aktivitas antioksidan edible film. Semakin tinggi total fenol dari penambahan bahan aktif dapat menghasilkan aktivitas antioksidan semakin tinggi 
Tabel 6. Aktivitas Antioksidan Perlakuan Konsentrasi Filtrat Kunyit Putih

\begin{tabular}{cc}
\hline Konsentrasi Filtrat Kunyit Putih & Aktivitas Antioksidan (\%) \\
\hline B1 (Filtrat kunyit putih dengan konsentrasi 0,8\%) & $9,49^{\mathrm{a}}$ \\
B2 (Filtrat kunyit putih dengan konsentrasi 1,2\%) & $14,71^{\mathrm{a}}$ \\
B3 (Filtrat kunyit putih dengan konsentrasi 1,6\%) & $23,67^{\mathrm{b}}$ \\
\hline
\end{tabular}

Keterangan : Nilai rata-rata yang diikuti huruf yang berbeda menunjukkan perbedaan nyata menurut uji Duncan (a 5\%).

Perlakuan penambahan filtrat kunyit putih berbeda nyata terhadap nilai antioksidan edible film. Nilai kadar antioksidan cenderung meningkat dengan peningkatan konsentrasi filtrat kunyit putih. Antioksidan tertinggi diperoleh pada perlakuan penambahan filtrat kunyit dengan taraf tertinggi yaitu perlakuan B3 (konsentrasi filtrat kunyit putih 1,6\%) dengan nilai sebesar 23,67\%, sedangkan nilai terendah terdapat pada perlakuan B1 (konsentrasi filtrat kunyit putih 0,8\%) sebesar 9,49\%. Semakin tinggi konsentrasi filtrat kunyit putih yang ditambahkan maka nilai aktivitas antioksidannya semakin besar. Hal ini sesuai dengan pernyataan (Suroto, 2012), bahwa semakin besar konsentrasi ekstrak kunyit maka kapasitas penangkapan radikal bebas semakin meningkat. Menurut saefuddin, dkk (2014), Semakin besar komponen bioaktif dalam filtrat menyebabkan nilai absorbannya semakin berkurang akibat adanya pertambahan aktivitas antioksidan. Komponen bioaktif yang terkandung dalam kunyit putih meliputi fenol total, flavonoid total, dan tannin yang bersifat antioksidan dan antimikroba (Pujimulyani, 2010).

\section{KESIMPULAN}

Berdasarkan data yang diperoleh dari penelitian yang telah dilakukan kesimpulan yang dapat diambil yaitu: Terdapat interaksi antara perbedaan konsentrasi gliserol dan konsentrasi filtrat kunyit putih terhadap parameter transparasi pada edible film yang dihasilkan. Perbedaan konsentrasi gliserol memberikan pengaruh nyata terhadap parameter ketebalan, persen pemanjangan (elongasi), dan nilai transparasi edible film. Perbedaan konsentrasi filtrat kunyit putih memberikan pengaruh nyata terhadap parameter nilai transparasi dan antioksidan pada edible film. Perlakuan terbaik pada penelitian ini dihasilkan oleh perlakuan A2B1 (Gliserol 1\% dan filtrat kunyit putih 0,8\%) dengan hasil nilai ketebalan $0,11 \mathrm{~mm}$; kuat tarik 0,44 $\mathrm{MPa}$; elongasi 6,34\% ; transparansi 2,73 A. $\mathrm{mm}^{-1}$; WTVR $2,25 \mathrm{~g} / \mathrm{m}^{2} /$ hari ; dan antioksidan $13,54 \%$. Edible film yang dihasilkan cocok untuk di aplikasikan pada produk olahan daging yang mengandung lemak. 


\section{DAFTAR PUSTAKA}

Akili, M. S., Ahmad, U., \& Suyatma, N. E. 2012. Karakteristik Edible Film dari Pektin Hasil Ekstraksi Kulit Pisang. Jurnal Keteknikan Pertanian, 26 (1), pp. 39-46. https://doi.org/10.19028/jtep.026.1.\%25p

Alam, F. and Hasnain, A., 2009, Studies on swelling and solubility of modified starch fromTaro (Colocasia esculenta): Effect of $\mathrm{pH}$ and temperature. Agriculturae Conspectus Scientificus, 74, pp. 45-50.

Amaliya, R. R., \& Putri, W. D. R. 2013. Karakterisasi Edible Film dari Pati Jagung dengan Penambahan Filtrat Kunyit Putih sebagai Antibakteri [in press juli 2014]. Jurnal Pangan dan Agroindustri, 2 (3), pp. 43-53.

ASTM. 2012. Standard Test Method for Tensile Properties of Thin Plastic Sheeting (D882). Annual Book of ASTM Standards. American Society for Testing dan Material, Philadelphia.

Bourtoom, T. 2007. Effect of Some Process Parameters on The Properties of Edible Film Prepared from Starch. Department of Material Product Technology. Songkhala.

Cerqueira MA, Bourbon AI, Pinheiro AC, Martins JT, Souza BWS, Teixeira JA, Vicente AA. 2011. Galactomannans use in the development of edible films/ coatings for food applications. Trends in Food Science and Technology, 22(12), pp. 662-671. https://doi.org/10.1016/j.tifs.2011.07.002

Coniwanti, P., Laila, L., \& Alfira, M. R. 2015. Pembuatan Film Plastik Biodegredable dari Pati Jagung dengan Penambahan Kitosan dan Pemplastis Gliserol. Jurnal Teknik Kimia, 20 (4).

Harini, N., Wachid, M., \& Hirgawati, T. A. 2020. Kajian Penambahan Filtrat Kunyit dan Tartrazin Pada Edible Film Berbasis Pati Talas Serta Aplikasinya Untuk Mempertahankan Mutu Dodol Substitusi Rumput Laut (Eucheuma cottonii). Food Technology and Halal Science Journal, 3 (1), pp. 34-46. https://doi.org/10.22219/fths.v3i1.13059

Huri, D., \& Nisa, F. C. 2014. Pengaruh Konsentrasi Gliserol dan Ekstrak Ampas Kulit Apel Terhadap Karakteristik Fisik Dan Kimia Edible Film. Jurnal Pangan dan Agroindustri, 2 (4), pp. 29-40.

Irawan, S. 2010. Pengaruh Gliserol Terhadap Sifat Fisik Mekanik dan Barrier Edible Film dari Kitosan. Jurnal Kimia dan Kemasan, 32 (1), pp. 6-12. https://doi.org/10.24817/jkk.v32i1.2735

Karmakar, R., Ban, D. K.and Ghosh, U. 2014.Comparative study of native and modified starches isolated from conventional and nonconventional sources. International Food Research Journal, 21(2), pp. 597-602

Muin, R., Anggraini, D., \& Malau, F. 2017. Karakteristik Fisik dan Antimikroba Edible Film dari Tepung Tapioka dengan Penambahan Gliserol dan Kunyit Putih. Jurnal Teknik Kimia, 23 (3), pp. 191-198.

Nisah, K. 2018. Study Pengaruh Kandungan Amilosa dan Amilopektin Umbiumbian terhadap Karakteristik Fisik Plastik Biodegradable dengan Plastizicer Gliserol. BIOTIK: Jurnal Ilmiah Biologi Teknologi dan Kependidikan, 5(2), pp. 106-113. http://dx.doi.org/10.22373/biotik.v5i2.3018 
Pangesti, A. D., Rahim, A., \& Hutomo, G. S. 2014. Karakteristik Fisik, Mekanik dan Sensoris Edible Film dari Pati Talas pada Berbagai Konsentrasi Asam Palmitat. Disertasi. Tadulako University

Polnaya, F. J., Ega, L., \& Wattimena, D. 2016. Karakteristik Edible Film Pati Sagu Alami dan Pati Sagu Fosfat dengan Penambahan Gliserol. Agritech, 36 (3), pp.247-252. https://doi.org/10.22146/agritech.16661

Pujimulyani, D., S. Raharjo, Y. Marsonce o, U. Santoso. 2010. Aktivitas Antioksidan dan Kadar Senyawa Fenolik pada Kunir Putih (Curcuma manga Val.) Segar dan Setelah Blanching. Agritech, 30 (2), pp.68-74. https://doi.org/10.22146/agritech.9675

Putra Anugerah Dwi, Vonny S. J., Raswen E. 2017. Penambahan Sorbitol sebagai Plasticizer dalam Pembuatan Edible film Pati sukun. Jurnal Pertanian, 4 (2), pp. 1-15.

Rita, W. S. 2010. Isolasi, identifikasi, dan uji aktivitas antibakteri senyawa golongan triterpenoid pada rimpang temu putih (Curcuma zedoaria (Berg.) Roscoe). Jurnal Kimia, 4(1), pp.20-26

Rusli, A., Metusalach, S., \& Tahir, M. M. 2017. Karakterisasi Edible Film Karagenan dengan Pemlastis Gliserol. Jurnal Pengolahan Hasil Perikanan Indonesia, 20 (2), pp. 219-229.

Saefudin, S., Syarif, F., \& Chairul, C. 2014. Potensi Antioksidan dan Aktivitas Antiproliferasi Ekstrak Kunyit Putih (Curcuma Zedoaria Rosc.) pada Sel Hela. Widyariset, 17(3), pp. 381-389. http://dx.doi.org/10.14203/widyariset.17.3.2014.381-389

Saputra, S. H., \& Purwanti, T. 2016. Karakteristik Kandungan dan Aktivitas Antioksidan Ekstrak Kunyit Putih (Curcuma zedoaria (Berg.) Roscoe). Jurnal Riset Teknologi Industri, 6 (11), pp. 80-87. http://dx.doi.org/10.26578/jrti.v6i11.1511

Saragih, I. A., Restuhadi, F. \& Rossi, E. 2016. Kappa Karaginan Sebagai Bahan Dasar Pembuatan Edible Film Dengan Penambahan Pati Jagung (Maizena). (Skripsi). Riau University.

Warkoyo, W., Rahardjo, B., Marseno, D. W., \& Karyadi, J. N. W. 2014. Sifat Fisik, Mekanik dan Barrier Edible Film Berbasis Pati Umbi Kimpul (Xanthosoma Sagittifolium) yang Diinkorporasi dengan Kalium Sorbat. Agritech, 34 (1), pp. 72-81. https://doi.org/10.22146/agritech.9525

Wulandari, G. A. 2021. Variasi Penambahan Kitosan dalam Pembuatan Bioplastik dari Limbah Sekam Padi dan Minyak Jelantah. Jurnal TEDC, 15 (1), pp. 814.

Yulianingsih, E., Sulistyoningsih, M., \& Ulfah, M. 2016. Pengaruh Penambahan Ekstrak Nanas dan Lama Pemasakan Terhadap Kadar Protein dan Organoleptik Tahu Susu. Bioma: Jurnal Ilmiah Biologi, 5(2), pp.50-64. https://doi.org/10.26877/bioma.v5i2.2523 